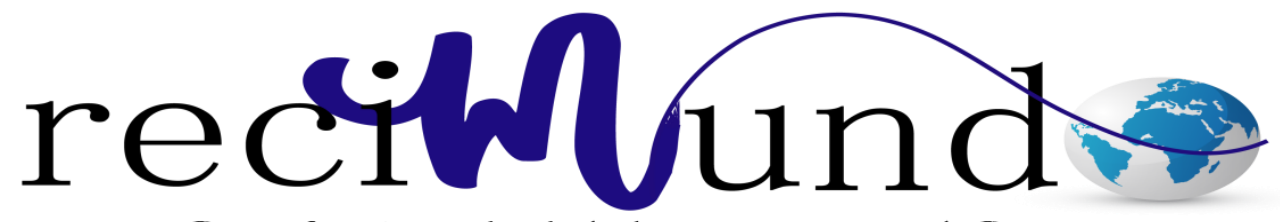

Revista Científica Mundo de la Investigación y el Conocimiento

Gioconda Avilés Villón ${ }^{\text {a }}$, Wendy Sánchez Cano ${ }^{\text {b }}$

Differences in using language between men and women

Revista Científica Mundo de la Investigación y el Conocimiento. Vol. 1 núm., 5, diciembre, 2017, pp. 547-558

DOI: 10.26820/recimundo/1.5.2017.547-558

Editorial Saberes del Conocimiento

a. Universidad de Guayaquil; gioconda.avilesv@ug.edu.ec

b. Universidad de Guayaquil; wendy.sanchezc@ug.edu.ec 


\section{Differences in using language between men and women}

Vol. 1, núm. 5., (2017)

Gioconda Avilés Villón; Wendy Sánchez Cano

\section{RESUMEN}

Los especialistas han dedicado mucho tiempo a la forma diferente en que los hombres y las mujeres usan el lenguaje. Este artículo muestra una breve descripción de los primeros investigadores relacionados con la creencia de que los hablantes femeninos y masculinos podrían diferir de alguna manera en su comportamiento comunicativo, pero estas diferencias deberían pensarse desde varias dimensiones, como género, edad, clase y grupo étnico. Lingüísticamente las diferencias entre los sexos se pueden ver como la forma en que los hombres o las mujeres usan el lenguaje. Además, presentaremos en este trabajo dos enfoques que pretenden dar una definición sobre cómo los diferentes géneros utilizan su competencia comunicativa que ayudará a los docentes a ser conscientes para aplicar las estrategias adecuadas para el aprendizaje de los estudiantes.

Palabras Claves: Diferencias, lenguaje, competencia comunicativa, género. 


\title{
Differences in using language between men and women
}

Vol. 1, núm. 5., (2017)

Gioconda Avilés Villón; Wendy Sánchez Cano

\begin{abstract}
Specialists have dedicated a long time to the different way men and women use language. This paper shows a brief description of the first researchers related to the belief that female and male speakers might somehow differ in their communicative behavior but, these differences should be thought from various dimensions such as gender, age, class, and ethnic group. Linguistically the differences between the sexes can be seen as the way men or women use the language. Moreover, we will present in this paper two approaches that intend to give a definition on how the different genders use their communicative competence that will help teachers to be aware in order to apply the adequate strategies for students learning.
\end{abstract}

Keywords: Differences, language, communicative competence, gender. 


\section{Differences in using language between men and women}

Vol. 1, núm. 5., (2017)

Gioconda Avilés Villón; Wendy Sánchez Cano

\section{Introducción.}

Language supplies us ways to express our thoughts, consequently our thinking is influenced by the language we use. As Wardhaugh states " communication among people who speak the same language is possible because they share such knowledge, although how it is shared - or even how it is required - is not well understood" (2006, p. 2). In this paper we will talk about the differences between the two genders: masculine and feminine, and the different kinds of relationship between them, as languages and societies are constantly changing.

First, it is essential to analyze the terms sex and gender. Sex refers to a biological distinction, while gender is the term used to describe socially constructed categories based on sex. Furthermore, it is necessary to point out the features women and men have in many fields. Physically speaking, women have more fatty tissue and less muscle, men are stronger than women and women mature more rapidly and generally live for more years. There are important social factors to take into account, such as; women might survive longer than men due to the divergent roles they have in society and jobs they are inclined to do. Men usually have more pressure than women in life hence they are the support of the family. Under these circumstances, the same language women and men speak can be different in the way they use it through time.

\section{Literature Review.}

Many years ago men were seen as the heart of the society, the important positions were held by men in all fields, like government, church, companies, etc. Women were considered invisible and linguistically deficient in comparison to men. Gradually, during the twentieth century, opinions of women began to change due to their role in the war which impulse women to the 


\section{Differences in using language between men and women}

Vol. 1, núm. 5., (2017)

Gioconda Avilés Villón; Wendy Sánchez Cano

sexual revolution of the sixties and seventies. In the early 1960's some researches were done about the belief that female and male speakers might somehow differ in their communicative behavior. The first scientist to study the important role of sex/gender in sociolinguistic was Labov in 1966. His studies reveal the different phonological variables according to sex/gender, age, socioeconomic status, and situational context. He highlighted two features of human language behavior:

a) Women of all classes and ages use more standard variants than their equivalent men. b) Middle class language is more standard in order to gain prestige.

In 1975, women achieved the legal right to be treated as the equals of men. This achievement brought some changes for women in the workplace, and at home, consequently some changes in attitude arose, too. According to Coates (1989) men and women differ in terms of their communicative behavior, but these differences should be thought from various dimensions such as gender, age, class, and ethnic group. Linguistically the differences between the sexes can be seen as the way men or women use the language. Considering these differences of women in society, linguists have approached language and gender from two different perspectives: the dominance approach and the difference approach (Coates, 2013).

For the dominance approach, the differences in language are considered as a reflection of the traditional roles in society, that is, dominance for men and subordination for women. These differences can be seen in speech too, when men lead the conversations. Robin Lakoff did the first research about the differences in gender speech and wrote her book "Language and 


\section{Differences in using language between men and women}

Vol. 1, núm. 5., (2017)

Gioconda Avilés Villón; Wendy Sánchez Cano

Women's place" in 1975 which had a lot of influence in other researches related to women speech.

Lakoff provides a list of ten linguistic features which characterize women's speech as follows:

1. Lexical hedges or fillers, e.g. you know, sort of, well, you see.

2. Tag questions, e.g. she's very nice, isn't she?

3. Rising intonation on declaratives, e.g. it's really good?

4. "Empty" adjectives, e.g. divine, charming, cute.

5. Precise color terms, e.g. magenta, aquamarine.

6. Intensifiers such as just and so, e.g. I like him so much.

7. "Hypercorrect" grammar, e.g. consistent use of standard verb forms.

8. "Super polite" forms, e.g. indirect requests, euphemisms.

9. Avoidance of strong swear words, e.g. fudge, my goodness.

10. Emphatic stress, e.g. it was a BRILLIANT performance.

According to Lakoff (1975) these features show that women have lack of confidence at the moment of interacting. Holmes (2001) split the list into two groups. The first one, "linguistic features" is related to the use of hedges or changing the stress of sentences that lacks assertive efficiency; such as tag questions, fillers, and rising intonation on statements. The second one, features that can intensify or improve a preposition's force; like the use of intensifiers. It demonstrates that the women speech would not be taken seriously. Another important issue that Lakoff relates is the great agreement between femininity and confused speech which is displayed 


\section{Differences in using language between men and women}

Vol. 1, núm. 5., (2017)

Gioconda Avilés Villón; Wendy Sánchez Cano

in a society dominated by men since women tend to present their female features of fragility and subordination toward men.

The difference approach is related to power and status differences between men and women. At the moment of speaking, men are interested on sharing information while women are interested in the interaction process, besides, it is important to mention that women and men have different ways of interaction since they come from different sociolinguistic subcultures which can lead to misunderstandings (Maltz \&Borker, 1982, cited by Xia, 2013). Tannen (1994) states that the women language is primarily "rapport-talk" where they negotiate with the purpose of being supportive. On the other hand, men language is "report-talk" where they demonstrate their independence, knowledge and skill.

Some relevant linguistic features are important to take into account at the moment of analyzing a conversation based on the two approaches already mentioned.

A. Men and women have different ways to phrase commands. Men generally use simple, direct statements whereas women use suggestions or indirect statements for actions. The indirectness can bring two advantages: rapport and defensiveness. When the speaker motivates the listener to go in the same direction that is Rapport. On the other hand, defensiveness refers to the preference of the speakers not to modify their ideas in case it does not receive agreement. (Holmes, 2001)

B. Women use tag questions in their speech that makes it weaken. However, some researchers have included "context" as an important factor in the use of tag questions which is related to conversational role rather than gender. Homes (2001) describes four 


\section{Differences in using language between men and women}

Vol. 1, núm. 5., (2017)

Gioconda Avilés Villón; Wendy Sánchez Cano

functions of tags questions that express uncertainty, facilitative, softening and confrontational. Examples:

Softening: You can't play basketball...can you?

Facilitative: Looks good.....doesn't it?

Confrontational: You didn't get books, did you?

Uncertainty: You will work....won't you?

C. Women prefer to use linguistics forms rather than men. There are two reasons for it.

Firstly, women in our society are generally more status-conscious than men, and therefore more sensitive to linguistic norms. Secondly, working-class speech has connotations of or associations with masculinity, which may lead men to be more favorably disposed to non-standard linguistic forms than women. (Trudgill, 1983, p.87).

On the whole, women's language is better and more correct.

D. Minimal responses are known as brief comments supplied by listeners during a conversation, through them; the listeners prove their active participation in the conversation (Coates, 1989). Typical examples are mmm, uh huh, yes, yea, and right. Several researchers have pointed out that women take the role of facilitator whereas men are less reactive to the process of interaction.

E. In a conversation is important the turn-taking procedures which enable speakers to keep a conversation without talking at once. According to White (2003), women disregard rules 


\section{Differences in using language between men and women}

Vol. 1, núm. 5., (2017)

Gioconda Avilés Villón; Wendy Sánchez Cano

of the turn-taking procedure less frequently than men do, on the other hand, women are more interrupted than men.

F. According to Lakoff (1975) women generally answer questions with rising intonation pattern rather than falling intonation; due to lack of confidence. On the contrary, men use falling intonation to display reliability on what they are saying.

G. Men and women use distinct words to show their feelings. Women use some adjectives (adorable, charming, heavenly, etc.) that men seldom use them. Furthermore, women generally avoid using swear words, different from men that they have the habit of swearing. Other difference is that women like to use diminutives (hanky, panties, etc.) and words to display affection (sweetie, dearie).

H. Since women and men have different interests their interaction topics will be different too. Men usually talk about economy, sports, current news while women talk about family affairs, such as clothes, cooking, children, etc.

I. Women's pronunciation is better than men's; this can be seen at the moment of learning a second language when girls show a better ability in language.

Besides realizing the differences between men and women, it is important to find out what the causes of these differences are. Some studies related to physical differences established that men have the phonological process in the left part of the brain which is related with the logic, facts, rules, math, and science. On the contrary, women use the right part of the brain which is related to feelings, symbols, images, believes, appreciates, spatial perception, fantasy based, impetus among others. It is said that women are concentrated on the "How" and men on the "What". 


\section{Differences in using language between men and women \\ Vol. 1, núm. 5., (2017) \\ Gioconda Avilés Villón; Wendy Sánchez Cano}

Other researchers employed different analytical categories with the purpose of understanding these distinctions and take from the Psychology, Social status and cultural background aspects. In the Psychology facet, women are more sensitive, polite and careful than men. In other words, women think before talking considering the effects their words will have. Men usually say what they want to without thinking about others.

Regarding the social status side, the level of education marks a great difference in speech between men and women. Moreover, genders differ in the kinds of language they use and the way they utilize it according to the roles they play in society. In the past, men used to have better positions in the labor field, as well as, women were considered inferior from them. Nowadays, women have achieved better positions in the society for their constant desire of improve.

People have their own way of thinking and also different kinds of lives, therefore this cultural phenomena lead people to create their own rules of languages. Lakoff (1975) states the differences of language, between men and women, come from their culture. Consequently, the cultural background has great influence in people behavior, including language.

\section{Conclusion.}

Summing up, this paper has shown valuable differences in the use of language between women and men from different aspects which can help us to understand the genders linguistic features according to their nature.

It is important to realize that all the gender differences in first language speech behavior are transferred to second language learning strategies since they are associated with their social 


\section{Differences in using language between men and women}

Vol. 1, núm. 5., (2017)

Gioconda Avilés Villón; Wendy Sánchez Cano

status, biological and psychological traits. According to Richards and Platt, learning strategies are "Intentional behavior and thoughts used by learners so as to better help them understand, learn or remember new information" (1992, p.209). Consequently, teachers should take these differences into account at the moment of planning a lesson, forming groups, choosing a topic for developing in class; in general each group requires different teaching styles in order to achieve their goals.

It is hoped that his paper can be used to improve the teaching practice and the performance of ESL students.

\section{References.}

Coates, J. (1989). Women in their Speech Communities. New York: Oxford University Press.

Coates, J. (2013). Women, Men and Language. A Sociolinguistic Account of Gender Differences in Languages. New York: N.Y.

Holmes, J. (2001). An Introduction to Sociolinguistics. New York: N.Y.

James, D., and Clarke S. (1993) 'Women, Men and Interruptions A Critical Review', in Deborah Tannen (ed.) Gender and Conversational Interaction. Oxford University Press: New York and Oxford.

Lakoff, R. (1975) Language and Women's Place. New York: Harper and Row Publishers, Inc.

Maltz, D. \& Borker, R.(1982). A Cultural Approach to male-female Miscommunication. Oxford: O.X.

Richard, J. \& Platt, J. (1992). Longman Dictionary of Language Teaching and Applied Linguistics. Essex: Longman.

Tannen, D. (1994). Gender and Discourse. New York: Oxford University Press.

Trudgill, P. (1983). Sociolinguistics: An Introduction to Language and Society.

Wardhaugh, R. (2006). An introduction to Sociolinguistics. Oxford: O.X 
Differences in using language between men and women

Vol. 1, núm. 5., (2017)

Gioconda Avilés Villón; Wendy Sánchez Cano

West, C. \& Zimmerman, D. (1985). Gender, language and discourse. Handbook of Discourse analysis. Vol. 4

Xia, X. (2013). Gender Differences in Using Language. Theory and Practice in Language Studies, Vol.3 (8) 1485-1489. 